\title{
Erratum to: The effect of gene copy number and co-expression of chaperone on production of albumin fusion proteins in Pichia pastoris
}

\author{
Qi Shen • Min Wu • Hai-Bin Wang •
}

Hua Naranmandura $\cdot$ Shu-Qing Chen

Published online: 8 September 2012

(C) Springer-Verlag 2012

Erratum to: Appl Microbiol Biotechnol

DOI 10.1007/s00253-012-4337-0

The original version of this article unfortunately contains a mistake. The name of the author should be Min Wu and not Ming Wu.

The online version of the original article can be found at http://dx.doi.org/ 10.1007/s00253-012-4337-0.

Q. Shen $\cdot$ M. Wu $\cdot$ H. Naranmandura $\cdot$ S.-Q. Chen $(\bowtie)$

Department of Pharmacology, Toxicology and Biochemical

Pharmaceutics, College of Pharmaceutical Sciences,

Zhejiang University,

Hangzhou 310058, China

e-mail: chenshuqing@zju.edu.cn

H.-B. Wang

Center of Technology, Zhejiang Hisun Pharmaceutical Co., Ltd,

Taizhou 318000, China 